\title{
Centro de Formação de Professores - SPQ
}

O interesse e a motivação dos jovens para o estudo e conhecimento da Química dependem fortemente da forma como os assuntos Ihes são apresentados pelos professores. Por isso, a atualização científica dos professores de química, a par da sua atualização em novas estratégias de ensino é, não só importante, como necessária.

Atenta às reais necessidades de formação dos professores de química, a SPQ, enquanto sociedade científica com a missão: ... promover, cultivar e desenvolver, em Portugal, a investigação, o ensino e a aplicação da Química... (Estatutos, Art. $^{\circ}$ n. ${ }^{\circ} 2$ ), criou em 2018 um Centro de Formação de Professores que se encontra acreditado pelo Conselho Científico-Pedagógico da Formação Contínua (CCPFC/DC1177/18).

Desde então foram acreditadas as Ações de formação: A Tabela Periódica: um Ícone na Centralidade da Química (CCPFC/ACC-101645/18), Nomenclatura química: adequação das regras da IUPAC à língua portuguesa (CCPFC/ACC-102892/19) e Conhecer a Luz para uma Cidadania Ativa (CCPFC/ACC-104322/19), cada uma com a duração de $25 \mathrm{~h}$, a que corresponde um crédito. No total, realizaram-se até à data 10 Ações presenciais e 3 à distância, por videoconferência. Além destas ações, e aproveitando a circunstância da realização dos Encontros de Divisão de Ensino e Divulgacção da

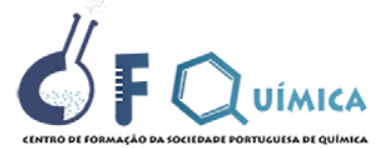

Química, promoveram-se Ações correspondentes a 0,5 créditos aquando da realização do VII Encontro da Divisão de Ensino e Divulgação da Química - VII EDEDQ (2018)e do Encontro de Ensino e Divulgação da Química (2019).

Tendo em conta as circunstâncias de pandemia em que vivemos, iremos promover, no primeiro trimestre de 2020-2021, várias Ações de Formação à distância, via videoconferência, ao abrigo da Carta Circular 3/2020 de junho de 2020 da CCPFC. Mantenha-se a par das Ações promovidas em formacao.spq.pt.

No sentido de continuar a promover a atualização cientíica dos professores de química, a SPQ procurará ampliar e continuar a promover Ações de formação que contribuam para a valorização e motivação dos professores de química. Para tal, a SPQ conta com o apoio e disponibilidade dos seus sócios.

Para além dos conhecimentos, disponibilidade e sentido de missão dos seus formadores (vide formacao.spq.pt), o Centro de Formação da SPQ pode dispor durante o ano letivo de 2019-2020 do apoio da professora Tânia Coelho (destacada), o que muito contribui para o sucesso das ações levadas a cabo. Hoje e sempre conta com o apoio do Leonardo Mendes para criar e manter o site e com o apoio da Cristina Campos para os aspetos administrativos.

Professora Maria Fernanda Carvalho

A Coordenadora do

Centro de Formação da SPQ

\section{EuChemS Comemora o seu $50 .^{\circ}$ Aniversário}

A European Chemical Society como a conhecemos agora, anteriormente Associação Europeia de Ciências Moleculares e Químicas (EuChems), teve origem em Praga no dia 3 de julho de 1970 como Federação das Sociedades Europeias de Química (FECS), numa reunião inaugural em que participaram 17 Sociedades Químicas Europeias.

A ideia de constituir uma organização guarda-chuva começou alguns anos antes, envolvendo principalmente representantes de sociedades químicas da Europa Ocidental, estendendo-se em seguida a países da Europa Oriental. Foi estabelecido um "Comité Diretivo", que se reunia alternadamente em cidades da Europa Oriental e Ocidental, e os seus membros dedicavam-se a promover uma cooperação internacional e a construir a imagem da Química Europeia, 